\title{
The social context of the Book of Job
}

\author{
Leon A Roper ${ }^{1}$ \\ (University of Pretoria)
}

\section{ABSTRACT}

\section{The social context of the Book of Job}

Although much has been written about the Book of Job, no consensus exists among scholars with regard to issues such as the dating and origins of this book. In this article the controversies surrounding the social context of the book of Job are discussed. This is followed by an attempt to reconstruct a possible socio-theological context for this book. In doing this, special attention will be given to the writer's possible relationship with the mainstream theological tradition of his day. This will be done by considering the possible aim of the "implied" author in constructing the book as well as the ways in which he has gone about achieving this aim. It is concluded that the implied author aimed to critically comment on the way in which the orthodox wisdom teachers of his time had clung to the traditional dogma of divine retribution. In doing this, this author seems to have employed various indirect techniques such as the use of a dramatic narrative to convey his message.

\section{INTRODUCTION}

Although much has been written about the Book of Job, no consensus exists among scholars with regard to issues such as the dating and origins of this book. If no certainty prevails with regard to these fundamental aspects of the book, it naturally follows that reconstructing a social context for the book becomes a rather difficult task. Clines (1989:Ivii) summarises this dilemma befittingly when he writes: "Unfortunately in the case of the book of Job, there is very little hard evidence of this kind, and we must rely largely on intelligent speculation". This task is even further complicated by the fact that it is generally believed that the author chose to place this narrative in a time and place remotely distanced from his own. As if this is not enough, such a reconstruction is further complicated by the seemingly different origins of different parts of the book.

1 Leon A Roper is a research-fellow of dr A Groenewald, Department of Old Testament Science, Faculty of Theology, University of Pretoria. 
In this article an attempt will, however, not be made to reconstruct any definite historical social context for the Book of Job. Attention will rather be given to the possible socio-theological context within which the Book of Job could have been written. In doing this, special attention will be given to the writer's possible relationship with the mainstream theological tradition of his day. This relationship will be examined along the lines of the writer's possible aim when writing this remarkable piece of work. The question that will be considered in the course of this article will thus be: what did the Joban author want to say to and about his contemporary theologians and why? In considering this question attention will also be given to the way in which the author went about achieving this aim. However, before an attempt will be made to shed some light on these issues, some consideration will firstly be given to the already mentioned controversies surrounding the date and origins of the Book of Job.

\section{CONTROVERSIES SURROUNDING THE DATE AND ORIGINS OF THE BOOK OF JOB}

\subsection{Date}

With regards to the time of origin of the book of Job, Rowley (1970:21) draws our attention to the fact that dates from patriarchal times up until the second or first century BCE have been assigned to the book. According to Rowley (1970:21) the earliest dating of the book is to be found with authors who, like the ancient tradition, ascribe the authorship of the book to Moses. This point of view seems to draw from the fact that the Talmud ascribes the book of Job to Moses due to the patriarchal setting of the prose tale.

Most modern scholars, however, seem to be in agreement that the book can be dated somewhere between the seventh and second centuries BCE with the probability that a prose folktale about a pious sufferer had existed long before the book itself was written (Clines 1989:1vii). Of these some, like Andersen (1976:63), have argued that the book originates from the time of King Solomon, a time during which Hebrew literature flourished and the wisdom literature in particular experienced a golden age.

Others, such as Terrien (1954:891), have thought that the suffering of Job may have been representative of the suffering of the Jews during the Babylonian exile and might therefore have been written during the exilic period. Such an argument for an exilic date 
for the book is also often substantiated by comparing the book to other passages in the Old Testament. In this regard passages, such as Psalms 49 and 73 which touch on similar issues than the book of Job and which are believed to have originated during the exilic period, are often utilised. Dell (1991:161), however, points out that the exilic dating of these Psalms is by no means conclusive which necessarily renders such inference rather problematic.

Despite such weaknesses in arguments drawing from literary dependency, parallels to various other biblical texts have also been drawn in an attempt to come to some conclusions with regard to the date of the Book of Job. In this regard Habel (1985:41) describes some attempts that have been made to date the book by citing similarities in form and thought between sections of the Book of Job and, among others, Jeremiah 20:14-18, Genesis 1 and Isaiah 40-55. Such similarities have been examined in order to attempt to locate the Book of Job in a common period when similar ideas and forms were prevalent. Habel (1985:41) also draws attention to the fact that some scholars have in their attempts to date the book entertained the possibility that the Joban author had made use of these similar passages. The problem with dating the Book of Job on the basis of such comparisons with other passages is, however, that no certainty exists with regard to which writer consulted which passage. Dell (1991:161) plausibly refers to this dilemma when writing: "... the direction in which such interdependence occurs is often indeterminable".

Conclusions with regard to the origins of the Book of Job have likewise been drawn from the reference to Job found in Ezekiel 14:14-20 (Perdue 1991:75). Clines (1989:lvii), however, warns that this reference may very well not refer to the book of Job but rather to a more ancient folktale. He is thus of the opinion that no inference about the date of the book can be drawn from this reference. The only inference that can possibly be made from this reference is that a character called Job was known about at the time of the exile and that he was regarded as a righteous man alongside Noah and Daniel. Habel (1985:41) concludes on this matter by arguing that while the author of Job had clearly been familiar with different literary and oral traditions of Israel, no proof of dependency for establishing a particular date for the book is demonstrable. 
For recent scholars, such as Habel (1985:42) and Dell (1991:162), the most popular period to assign the Book of Job to is the post-exilic period. This is normally done on the grounds that the book is viewed as an answer to the theology of divine retribution which was very prominent before and during the exile, particularly among the exilic prophets (Dell 2000:360). Such a post-exilic dating of the book is sometimes also substantiated by the argument that "the Satan" is a character mentioned only in post-exilic literature and that the angelology of the Book of Job finds its closest parallel in those sections of the book of Daniel dated in the second century BCE (Niehr 2004:510, 512; Peake 1905:40; SchwienhorstSchönberger 2004a:344; cf. also Haag 2003:133-142, 232ff.).

A last argument that has been quite popular among scholars with regard to the dating of the Book of Job is one that allows for different stages in the development of the book. Scholars are, however, once again not in agreement over the nature and dates of these stages. In this regard Snaith (1968:34-44) proposes three editions of the book by the same author. These editions are identified as follow: 1) a shortened prologue and shortened epilogue (without the three friends), Job's soliloquy, Yahweh's replies with an apology and submission by Job; 2) the present prologue and epilogue, the three friends, some miscellaneous pieces in chapters 24-28 and all the poetic pieces of the first edition, and; 3 ) the book in its present form with the Elihu speeches inserted at the end of the dialogue after all the humans have finished speaking but before the divine speeches of chapters $38-41$.

Perdue (1991:76), again, in following a long tradition of scholarship, allows for stages in the development of the book along the lines of the history of ancient Israel. The trajectory that he suggests is as follows: the prose narrative during the monarchy, the poetic dialogues during the exile and Job 28 and the Elihu speeches after the exile. There are indeed many scholars who agree with Perdue in believing that some of the major elements of the book, namely the narrative parts (prologue and epilogue), the speeches of Elihu in chapters 32-37 and the poem of wisdom in chapter 28, have been written either earlier or later than the main body of the text namely the poetic dialogues. These arguments are normally based on the differences in style and content found in the respective parts, but are once again not conclusive with regard to the dating of these sections. 
All the above-mentioned arguments thus remain relative as the Joban text offers no explicit historical references which would suggest a particular period within which the book was constructed (Habel 1985:42). This lack of historical reference naturally also complicates the search for the origins of the book - a topic to be discussed below.

\subsection{Origins}

With regards to the origins of the book of Job, Dell (2000:360) points out that the quest for an author for the book is particularly complicated by the fact that the book itself provides no evidence of a specific event or social situation that precipitated the writing thereof. This issue is even further complicated by the fact that Job is the only 'wisdom' book that is not ascribed to Solomon or some other specifically named author. The result hereof is that we, once again, find several divergent opinions among scholars regarding this matter. These scholars can be divided into two major categories, namely those who have attempted to find a specific named author for the book and those who have searched for a rather general unnamed author.

Among those scholars who have opted for a specific named author the most popular option has certainly been the already mentioned Mosaic authorship. In this regard Dell (1991:160) points out that the "Mosaic authorship is still maintained by some conservative scholars who point to the reference in Baba Bathra, $14 \mathrm{~b}, 15 \mathrm{a}$ - 'Moses wrote his own book, and the passages about Balaam and Job"'. Another author to have opted for a specific named author for the book is Wolfers (1995:54) who ascribes the book to the prophet Isaiah on the basis of a range of some similarities between the two books.

The consensus of scholarly opinion, however, seems to opt for a reconstruction of a broader category or group to which the Joban author might have belonged to. In this scholarly camp many different opinions are once again to be found. Gordis (1965:209211), for example, points to the fact that various authors such as the medieval Hebrew commentator and grammarian Abraham ibn Ezra and, centuries later Carlyle, Renan and Tur Sinai have argued that the Book of Job must be regarded as a Hebrew translation of an original Arabic work. Complexities such as the various identified Aramaisms and Arabic parallels, as well as the universal stance 
presupposed in the text paired with the seemingly absence of Hebraic ideas, seem to have influenced these scholars' arguments (Gordis 1965:211). Gordis (1965:211-213), however, disagrees with this premise and argues that such complexities can in fact be regarded as evidence for its authenticity.

Another group of scholars, including Pfeiffer (1926:13-25), again believe that the Book of Job is a product of Edomite wisdom. This argument is mostly based on theories that various Edomite references are to be found in the book, such as the friends' names and certain locations such as Uz. Although, as Day (1994:397-398) has suggested, these factors may indicate that the character Job can be regarded as an Edomite, they can by no means be regarded as conclusive about the origins of the author of the Book of Job. The author might indeed have decided to place his narrative in a foreign setting with foreign characters.

A further possibility suggested by authors, such as Humbert (in Rowley 1970:22) is that the Book of Job is of Egyptian origin. In substantiating this argument attention is drawn to the extensive development of wisdom literature in Egypt. Various writers have indeed also cited some similarities between the Joban text and several ancient Egyptian texts which could have possibly served as sources for the author of Job. In this regard Snaith (1968:19-20) points to the book of Job's similarities with three known Egyptian texts, namely The Complaints of the Eloquent Peasant, The Prophecy of Nefer-Rohu and A Dispute over Suicide. Snaith (1968:20) remarks that all three of these Egyptian texts, like Job, consist of a prologue and epilogue in prose form which serves as a frame for a more poetic piece. Apart from these similarities in form the last mentioned text has also been shown to display some thematic resemblance with the Book of Job in that it is also concerned with a man who had been grievously maltreated and consequently wished to die (Snaith 1968:20). The Joban author's extensive and detailed descriptions of Egyptian animals, such as Behemoth (the Hippopotamus) and Leviathan (the crocodile), are furthermore thought to point to an Egyptian origin for the book (cf also Schwienhorst-Schönberger 2004a:339). Such an origin is, lastly, also thought to be evident from the reference to 'ships of papyrus' found in Job 9:26 (Gordis 1965:212). 
Scholars, like Jastrow (1906:135-191), have again looked to Babylonia for the origins of the Book of Job. Jastrow (1906:135191) argues that the author of Job had made use of the so-called Babylonian Job (Ludlul bel nemeqi - "I will praise the Lord of wisdom") in constructing his text ${ }^{2}$. This Babylonian tale, which describes the suffering of a king by the name of Tabi-utul Bell who lived in Nippur, is thought to be a prototype of the Hebrew Job narrative. In response to this argument Snaith (1968:24-27) remarks that the parallels in motif and style between the Babylonian Job and sections of the Book of Job are so remarkable that they can scarcely be accidental. He therefore argues that the Joban author might have drawn from this tale in the construction of the book. However, authors like Driver and Gray (1964:1xv-lxvi) argue that no Babylonian associations are to be found in the Book of Job.

Although it is accepted that the Joban author might have been influenced by foreign traditions, most modern scholars, however, seem to be quite sure about the fact that the author was of Israelite origin (Rowley 1970:23; Andersen 1976:63; Habel 1985:40; Clines 1989:lvii; Dell 1991:162). Rowley (1970:23) argues in this regard that it is hard to think that the Joban author had not been of Israelite origin. He bases his argument on his observation that the author of Job had been a monotheist and worshipper of Yahweh - possibly influenced by Deuteronomic and post-Deuteronomic theology. For Rowley (1970:23) it is furthermore not surprising that no reference to the land or cult of Israel is made in the book, as the scene is set in the patriarchal age and the introduced characters are of non-Israelite origins. The foreign setting and characters are explained in the light of the fact that the book is believed to be based on an original nonIsraelite tradition adapted by the author for his specific purpose. The author is furthermore regarded as someone who had travelled extensively and who had been well acquainted with non-Israelite literature and traditions. Despite these external influences it is, however, argued that the profoundly spiritual message of the book can be understood much easier against the backdrop of the Old Testament religion, than in the setting of any other country of the Ancient Near East.

2 Schwienhorst-Schönberger (2004a:339-340) mentions more texts which could be regarded as parallel texts for the Book of Job. 
Not withstanding the above-mentioned consensus with regard to the Israelite origin of the Book of Job, Habel (1985:40) maintains: "The identity of the author, however, remains a complete enigma". It is in the light of this ongoing enigma that, for the purpose of this article, I will not attempt to reconstruct any historical actuality such as the date of the Joban text's composition or the identity of its author. Attempts will also not be made to describe the actual social matrix of the text. Instead, this opportunity will be utilised to ask questions and speculate about the implied socio-theological context within which the implied author might have found himself at the time of constructing the Book of Job. This means that inferences will be drawn from the text about the author and his circumstances as implied by my reading of the text. If I then refer to 'the author' from here onwards, it will necessarily refer to an implied author and not to any actual historical figure.

The considering of this implied author and his circumstances will mainly be done through the examining of the specific nature of the interactions between the characters of Job and the characters of his friends (Eliphaz, Bildad and Zophar) as found in the book of Job. In this regard it is important to note that for the purpose of this artice Elihu will not be regarded as one of Job's friends. This is the case, partly because of his absence from the prologue and epilogue, but also because I agree with Habel (1985:32) who views Elihu as an arbiter rather than a friend. Nevertheless, although it is believed with most scholars, like Habel (1985:37), that the third cycle of speeches between Job and his friends has suffered some dislocation, for the purpose of this exercise, the present available Joban text will be regarded as a single coherent unit with a well worked out plot. This implies that, in following Habel (1985:26), both the prologue and epilogue will be regarded as integral parts of this plot.

\section{TOWARDS A POSSIBLE SOCIO-THEOLOGICAL CONTEXT}

In an attempt to consider a possible socio-theological context for the Book of Job, consideration will be given to mainly two questions namely: what was the author's aim when writing the book? And, how did he go about achieving this aim?

\subsection{The aim of the implied author}

In considering the question about the author's aim in writing the book of Job I want to agree with Gordis (1965:213) who argues that 
the author is critically commenting on the orthodoxy of his time. Together with Gordis (1965:213-215) and Dell (1991:168) I want to argue that the author was trained in the wisdom tradition of Israel. Although very passionate about the practicing of wisdom (otherwise he would probably not have written the book), he most probably was concerned about certain wisdom practices of his time.

His experience seems to have been that the doctrine of divine retribution, as proclaimed by the orthodox wisdom teachers of his time, did not always hold truth for his own life or the lives of others with whom he came into contact ${ }^{3}$. He seems to have experienced that righteous people could suffer just as much (or even more) than the ungodly. This conclusion can be made if it is accepted with Clines (1994:13) and Dell (1991:171) that the author's experiences are expressed within the characters' described experiences. In this regard it is significant that we find several emotionally laden descriptions of Job's disillusionment with his friends' answers to his laments (cf Job 6:14-30). One could infer from this disillusionment that the author himself might have experienced severe disappointment regarding the orthodox wisdom teachers' answers to those lamenting their misfortune. The question that now arises from this inference is certainly, what is the nature of these unacceptable answers? In answering this question, brief consideration will be given to the doctrine underlying of Job's friends' answers to his laments. This

3 In this regard Berges (2001:243) infers as follows: "Als geen andere figuur in de bijbel blijkt Job niettemin in staat de tegenspraken in het leven duidelijk waar te nemen. Het bijbelse credo dat God rechtvaardig is en redding brengt, ondermijn die waarneming niet, maar verscherpt ze juist. De overtuiging van de bijbel dat God voor armen en achtergestelden een betrouwbare helper en pleitbezorger is, brengt de lijdende rechtvaardige, en juist hem, in een onpeilbare krisis. Job is niet bereid de werkelijkheid goed te praten om van de eer van zijn God te redden. In de hele bijbelse traditie is dan ook geen verschrikkelijker beschrijving van sociale ellende te vinden dan hij voorhoudt: “ ... Kreunend sterven ze overal in de stad, roepen gewond om hulp, maar God heeft geen oog voor deze verschrikking" (Job 24, 7-12). Op deze noodsituatie zou de Helper van de armen moeten reageren door in te grijpen, maar Hij roert zich niet! Klagend over de ellende wordt dan ook tot een aanklacht tegen God ... Het boek Job houdt niet alleen vast aan wat er in en aan de wereld irrationeel is, maar localiseert dat ook tot in het beeld zelf van God ... Het zekerheidwekkende beeld van een rechtvaardige God is voor hem, en daarom ook voor vele anderen, in stukken gebroken". Cf also Berges (1994:299ff) and Berges (2004:327). 
will be done as the friends' arguments are believed to reflect the doctrine endorsed by the orthodoxy of the author's time ${ }^{4}$.

Upon considering the speeches of Job's friends, I want to agree with scholars, such as Loader (1983:22ff), who argue that the friends were all committed to a well worked out theological system which provided clear cut answers to all human questions about suffering and God's dealings with human beings. If their answers did not correspond to people's specific situations, they believed that the blame had to be put on the one asking the question: he or she must have committed some sin (just like Job). Reality has thus been forced into a well worked out, preconceived scheme instead of taking into account people's real experiences. Even God and the way in which he operates were forced into this dogmatic scheme. The friends or, for that matter, the orthodox wisdom teachers of the author's time, fiercely defended their faith in a moral principle according to which they believed the world was ruled. In clinging to this principle they seem to have rejected any experiences (like Job's) which contradicted their beliefs. As such contradictory experiences or beliefs were probably seen as a denial of the basics of their theological system, they probably did not even give any thought to such experiences. Instead, in the case of such experiences it must have been declared immediately that the problem lay with the person having such contradicting (according to their system) experiences.

Such a theology thus assumed that God's actions could be explained completely in terms of a specific theological system. Everything that happened to people in this world could likewise be explained in terms of a certain set of rules such as the dogma of retribution. By using this scheme of theirs they seem to have concluded from people's circumstances whether they have sinned or not. The logic of the traditional wisdom as found for example in the book of Proverbs, namely that wise deeds would lead to positive consequences and unwise deeds to negative consequences, had thus

4 According to Schwienhorst-Schönberger (2004a:344) "die Ijobdichtung problematisiert und reflektiert in einer litararisch und sprachlich höchst kunstvollen Form die traditionelle weisheitliche Anschauung vom TunErgehen-Zusammenhang und dürfte demnach nicht zu den frühen Werken jüdischer Weisheitsliteratur zu rechnen sein". 
even been forced in the opposite direction. ${ }^{5}$ With Loader (1994:90) I want to argue that it seems as if the orthodox wisdom teachers have endowed themselves with the power to conclude from people's circumstances whether these people have been pious or not. People's experiences must thus have been regarded as inferior to the nonnegotiable orthodox theological system.

I want to argue that it is precisely because of such rigidity which the author must have experienced within the circles that he found himself in, that he felt compelled to write the book of Job. Such rigidity must have frustrated the author immensely. As the wisdom teachers must have been looked upon for answers to existential questions, the writer must have regarded it as important for them to be as correct as possible in the answering of these questions. For a wisdom teacher, who took his job seriously, it must have been a great source of frustration to hear his contemporaries answering people in distress with answers that possibly created even more distress.

Frustration is certainly very prominently depicted through the character of Job's replies to his friends. These replies of Job, whereby he expresses indictment with his friends for failing to fulfil their proper functions, are introduced by his statement in $6: 14^{6}$ (Habel 1985:148). In this statement Job declares that he expects compassion and loyalty from his friends, but instead they seem to regard these acts as too much of a burden. Instead of providing him with empathy during his difficult circumstances, his friends only provided him with traditional answers and these are absolutely useless in his circumstances. Job's experience has thus been that through their answers the friends revealed that they did not take his suffering seriously. Even if they genuinely wanted to help him they

5 With regard to an explication of the "doctrine of divine retribution", see Schwienhorst-Schönberger (2004b:378): "Die Grundstruktur weisheitlichen Denkens ist geprägt von einer Ordnungsvorstellung, die gern mit dem Begriff »Tun-Ergehen-Zusammenhang « bezeichnet wird. Dieser Vorstellung zufolge besteht ein Zusammenhang zwischen dem Tun und dem Ergehen eines Menschen und einer Gemeinschaft: Wer Gutes tut, dem ergeht es gut, wer Schlechtes tut, dem ergeht es schlecht. Dieser Zusammenhang betrifft die wirtschaftliche, soziale, und politische Dimension menschlichen Lebens".

6 This text reads as follows: "Those who withhold kindness from a friend forsake the fear of the Almighty" (NRSV). 
could not as they were too caught up in their commitment to their traditional ideas to truly listen to and acknowledge Job's experiences. For them it has become a power struggle whereby they first had to defend the traditional dogma of retribution before they could give consideration to people's real experiences as their reputation and that of their doctrine was certainly at stake.

From the above consideration of the interaction between Job and his friends it is inferred that the author wanted to protest against the conventional wisdom teachers' (represented by the friends) useless traditional answering of existential questions while unsympathetically negating real human experiences. It is as if he wanted to say to the orthodox readers that when people suffer, this does not necessarily mean that they have sinned against God and under such circumstances people need empathy and not condemnation. The question that now arises out of this conclusion is: how did the author go about conveying this message of his? - a question to be considered below.

\subsection{The implied author's strategies}

In this section I want to argue that, because of the sensitive nature of his message and its context, the implied author masterfully employed a series of subtle, indirect strategies in order to drive his message home. This indirectness and subtleness of the author's approach is, in my view, evident in a number of techniques employed by the author, namely his use of genre, setting and the doctrine of divine retribution.

With regard to genre, I would like to elaborate on the ideas of scholars such as Andersen (1976:34) and Westermann (1981:6) who point to the dramatic qualities of the book of Job. Andersen (1976:34) writes in this regard: "The dramatic quality of Job can be recognized without calling it a drama in the strict sense". I want to agree with this statement and also agree with Habel (1985:25-35) who points to a coherent plot development throughout the entire Book of Job. He (Habel) points out how this plot unfolds through a series of conflicts between Job and his friends on the one hand, and between Job and his God on the other hand. I believe that in developing his plot, the author might have employed a well-known folktale about a pious sufferer (as found in the prologue and epilogue) which he expanded on through the writing of the dialogue parts in order to dramatically express the conflict between the 
orthodox doctrine of retribution and people's actual experiences. In this drama the friends would be the antagonists who represent the orthodox wisdom teachers and Job the protagonist who represent the innocent sufferer.

By portraying his message in such a dramatic way the author clearly succeeded in tricking his audience into involvement in the debate about the doctrine of divine retribution that unfolds within the plot. By employing a dramatic narrative he, however, simultaneously distanced the debate from the real life context. This is the case because by employing a dramatic genre the author could portray his message without directly referring to any actual person or situation, although these could have been implied subtly. Such distance created through the use of a dramatic genre would have naturally increased the likelihood that the author's opponents would have reconsidered their own stance with regard to the doctrine of retribution. This can be argued, as the dramatic narrative is likely to have involved the audience as observers and, consequently, as commentators on the narrated plot and indirectly also of their own actions. It is highly unlikely that the orthodox readers would have reconsidered their position if the author attempted to directly oppose their doctrine in the form of an extensive theological discourse. Instead, the author thus wrote a dramatic narrative with real characters and real experiences to which people could relate to and which would have been very difficult to deny or argue with. The author thus subtly transforms the debate from a solely intellectual, doctrinal one to a more personal, and/or social one.

Secondly, the indirectness of the author's approach is demonstrated by his selection of a foreign setting for his narrative. I find it very significant that the author chose to set the narrative in a foreign place (Uz), with foreign characters from Teman (Eliphaz), Shuah (Bildad) and Naamath (Zophar), and within a distant time frame, namely that of the patriarchs. (This is of course the case if it is accepted with the majority of recent scholars that the author is an Israelite and that the book can be dated in post-exilic times.) The reason for this foreign setting may possibly be found in an ingenious attempt by the author to distant the narrative setting from his contemporary context in order to ensure a more sympathetic consideration for his criticism of the orthodox wisdom practices of his day. It is likely that, if the author would have been too frank about the fact that he was criticising the orthodox wisdom teachers 
of his day, both he and his message would have been rejected altogether, by precisely those people he most wanted to reach. The author thus employed a dramatic narrative set in a foreign context in order to provide his readers with an opportunity to reconsider their own behaviour from a more distant, objective point of view.

Thirdly, the subtle indirectness employed by the author to portray his message is also eminent in the way in which he uses the doctrine of retribution to bring his message home. Some authors, like Clines (1990:110-116), believe that the Joban author contradicts himself by undermining the philosophy he asserts. This is believed to be the case as it seems as if the author applies the principles of the doctrine of retribution while simultaneously criticising them. The application of these principles is for instance evident in Job's restoration described in the epilogue after God has proclaimed that Job has spoken rightly about Him. Job is thus rewarded by God for speaking the truth about Him even though this truth is that God does not follow such a logic of retribution. I am, however, of the opinion that the author could have used this contradiction purposefully in order to ensure the sympathetic acceptance of his message by his orthodox readers. As his readers were likely to be mostly uncritical of the traditional doctrine of retribution it would have obviously been futile to reject this doctrine straightforward. Instead, the author masterfully employed the principles of this doctrine in order to bring his readers to a point where they themselves reject this doctrine on the basis of its own principles. This seems to have been done by the development of the plot wherein Job is portrayed as the protagonist and his friends as the antagonists. In the unfolding of this plot the reader's sympathy for the character of Job is provoked by depicting him as a caricature of the pious person who suffers innocently.

To strengthen the reader's sympathy for Job even further, God is employed as a judge who, in the epilogue, passes judgement in the conflict between Job and his friends. Once again the principles of the doctrine of retribution (which the orthodox readers firmly believed in) are applied to prove Job's correctness in his argument with his friends. Job is rewarded for not allowing his friends to force the doctrine of retribution unto him. His friends, on the other hand, are reprimanded for unconditionally clinging to the doctrine of retribution. Because of their sympathy with Job and their acceptance of God as the highest authority, the orthodox readers would thus 
have been likely to reject the unconditional application of the doctrine of retribution at least in their reading of this narrative.

It does thus seem as if the author made use of a subtext in his writing of the Book of Job where the conflict between Job and his friends (or between the author and the orthodoxy of his time) was employed as a counter plot in the conflict between a pious sufferer and his God. This implies that, although it seems as if the main conflict in the plot is between Job and God, this should only be regarded as a smoke screen for the real conflict at hand, namely the conflict between Job and his friends or between the author and the orthodoxy over the application of the doctrine of retribution. God is furthermore subtly employed as the judge in this conflict who passes judgement in favour of Job and consequently also in favour of the author.

The question that arises from this conclusion is: what do these subtle indirect techniques employed by the author in achieving his aim have to say about his possible socio-theological context? I want to argue that these techniques highlight the author's ambiguity with regards to the wisdom tradition of his day as well as the harsh rigidity of this context. On the one hand he treasured the wisdom tradition and wanted to be part of it, but on the other hand he could not accept the rigidity with which the doctrine of retribution was applied within these circles. As a devoted wisdom scholar he could not completely distance himself from the wisdom tradition, but he could also not keep quiet about the wrong answers provided by his "friends" to very crucial questions. He was, however, also aware that because of the fierce rigidity of the orthodox wisdom teachers it would have been almost impossible to argue with them in a direct manner. The author therefore felt compelled to write a drama that would critically comment on wisdom practices of his time in such away that the orthodox readers would have been forced to accept its message.

\section{CONCLUSION}

In this essay the controversies surrounding the social context of the Book of Job have been discussed, where after an attempt was made to reconstruct a possible socio-theological context for the book. This was done by considering the possible aim of the author in constructing the book as well as the ways in which he has gone about achieving this aim. It was concluded that the author seemingly 
aimed to critically comment on the way in which the orthodox wisdom teachers of his time had clung to the traditional dogma of retribution. In doing this, the author seems to have employed various indirect techniques such as the use of a dramatic narrative to convey his message. This seems to have served the purpose of actively involving the readers in the argument against the unconditional application of the doctrine of retribution. It is as if the author wanted to encourage his readers, as they consider questions about suffering, to rather take on Job's attitude in Job 40:4 when he says: "Behold, I am of small account; what shall I answer thee? I lay my hand on my mouth".

\section{Consulted Literature}

Andersen, F I 1976. Job: An introduction and commentary. London: Tyndale Press (Tyndale Old Testament Commentaries).

Berges, U 1994. Hiob in Lateinamerika. Der leidende Mensch und der aussätzige Gott, in: Beuken W A M (ed), 297-317.

-, 2001. Zwijgen is zilver - klagen is goud: Pleidooi voor een herontdekking van het bijbelse klagen. Tijdschrift voor Theologie 41(3), 231-252.

-, 2004. Der Zorn Gottes in der Prophetie und Poesie Israels auf dem Hintergrund altorientalischer Vorstellungen. Biblica 85(3), 305-330.

Beuken, W A M (ed) 1994. The book of Job. Leuven: Peeters.

Buttrick, G A 1954. The interpreter's Bible 3. Nashville: Abingdon Press.

Clines, D J A 1989. Job 1-20. Dallas: Word Books (WBC 17).

-, 1990. What does Eve do to help? and other readerly questions to the Old Testament. Sheffield: Sheffield Academic Press (JSOT SS 94).

-, 1994. Why is there a book of Job and what does it do to you when you read it?, in Beuken W A M (ed), 1-20.

Day, J 1994. 'How could Job be an Edomite?', in Beuken W A M (ed.), 392399.

Dell, K J 1991. The book of Job as sceptical literature. Berlin: Walter de Gruyter (BZAW 197).

-, 2000. 'Wisdom in Israel', in: Mayes A D H (ed), 348-375.

Driver, S R \& Gray, G B 1964. A critical and exegetical commentary on the book of Job: together with a new translation. Edinburgh: T \& T Clark (The International Critical Commentary).

Gordis, R 1965. The book of God and man: a study of Job. Chicago: University of Chicago Press. 
Haag, E 2003. Das hellenistische Zeitalter. Israel und die Bibel im 4. bis 1. Jahrhundert v. Chr. Stuttgart: Kohlhammer (BE 9).

Habel, N C 1985. The book of Job: a commentary. London: SCM Press (OTL).

Jastrow, M 1906. A Babylonian parallel to the story of Job. Journal of Biblical Literature 25, 135-191.

Loader, J A 1983. Job - antwoord of enigma? Theologia Evangelica 16 (2), 15 31.

-, 1994. Die rebel wat die waarheid oor God gepraat het, in: Müller J C \& Vos C J A (reds), 87-98.

Mayes, A D H (ed) 2000. Text in context: essays by members of the Society for Old Testament Study. Oxford: Oxford University Press.

Müller, J C \& Vos, C J A (reds) 1994. Menswaardig. Halfway House: Orion.

Niehr, H 2004. Das Buch Daniel, in Zenger E (ed.), 507-516.

Peake, A S 1905. Job. Edinburgh: T C \& E C Jack (The Century Bible).

Perdue, L G 1991. Wisdom in revolt: metaphorical theology in the book of Job. Sheffield: Sheffield Academic Press (JSOT SS 112).

Pfeiffer, R H 1926. Edomitic wisdom. $Z A W 44$, 13-25.

Rowley, H H 1970. Job. Ontario: Thomas Nelson \& Sons (The Century Bible).

Schwienhorst-Schönberger, L 2004a. Das Buch Ijob, in Zenger E (hrsg.), 335347.

-, 2004b. Das Buch der Sprichwörter, in: Zenger E (ed.), 371-379.

Snaith, N H 1968. The book of Job: Its origin and purpose. London: SCM Press.

Terrien, S 1954. The book of Job, in: Buttrick G A, 877-1198.

Westermann, C 1981. The structure of the book of Job: a form-critical analysis. Philadelphia: Fortress Press.

Wolfers, D 1995. Deep things out of darkness: the book of Job: essays and a new English translation. Grand Rapids: Eerdmans.

Zenger, E (hrsg.) 2004. Einleitung in das Alte Testament. 5. Aufl. Stuttgart: Kohlhammer (Studienbücher Theologie 1,1). 